\title{
Technology of personnel training for the transport industry
}

\author{
Victoriya Alexandrovna Vinichenko ${ }^{1,2^{*}}$ \\ ${ }^{1}$ Novosibirsk State Technical University, 20, K. Marx street, Novosibirsk, 630073, Russia \\ ${ }^{2}$ Siberian State University of Water Transport, 33 Tshchetinkina street, Novosibirsk, 630099, Russia
}

\begin{abstract}
The paper is devoted to the study of modern educational technologies used to train specialists in the transportation industry. The prerequisites for updating and supplementing existing educational technologies are considered. Critical skills for various modes of transport are identified. The challenges of the global socio-economic architecture that dictate updated requirements to the educational environment are defined. A review of the world practice in training personnel for the transportation industry was carried out, and a comparative analysis of the technologies used in a number of countries was conducted. As a result, we have obtained a set of best practices used for training specialists in the field of transport. The comparative analysis shows that some practices are equally and successfully applied both in Russia and abroad. There are also specified some trends in the influence of processes occurring in transport on the further transformation of the industry's human resources. The direction for future research has been determined.
\end{abstract}

\section{Introduction}

The transportation industry is life-supporting, along with other socially important industries. The effectiveness of its functioning affects national security, global competitiveness and the performance of the economy. The peculiarity of the transportation industry is that transport, as a mechanism for ensuring the needs for cargo delivery and passenger transportation, simultaneously acts as a metric of the region's success, forming the investment, migration and tourist attractiveness of the region. However, the product of transport is a useful movement or service. The performance of the service depends largely on the performer. The quality of transportation services depends primarily on the employees employed in the transport sector. The role in the value stream for the customer is played by the employee engaged in the assembly of rolling stock, as well as by the employee of ticket offices, the driver, the dispatcher, and everyone who forms the human resources of transport enterprises.

The dynamism that occurs in transport is perhaps the most significant among other industries. Unless the market for mobile devices and computer equipment is developing at a faster pace. Business models in transport are changing significantly [1]. Today's rolling

\footnotetext{
* Corresponding author: vika_06.07@mail.ru
} 
stock is significantly different from what it was at the beginning of this century. It is strikingly different from the one that was in the last century. Today's trains, planes, cars, and ships are called "smart" and technology is called "green" [2]. The rolling stock can be controlled in the absence of a person, energy can be obtained from bio-elements, but for "filling" the car it is enough to connect it to an outlet. The changes taking place today are far from final and require new skills. This is not about skills for charging a car battery. The focus is on competencies that allow you to design such equipment, manage it, create software, provide technical support to users, and many other competencies that are becoming critical in the light of ongoing changes [3].

The purpose of this article is to create a list of technologies used in various countries of the world, taking into account existing trends in the field of transport, as well as to determine their impact on the further transformation of the industry's human resources.

\section{Materials and methods}

The paper uses methods such as information collection and processing, bibliographic description, classification, descriptive and historical methods, analysis and synthesis, comparison, and graphical method. The authors used the work of researchers from Finland, Denmark, the Slovak Republic, Singapore, the United Kingdom, the Czech Republic, France, Japan, Italy, Germany, India, Portugal and several other countries.

The study is built in blocks that are interconnected and dependent on each other. The links are both direct and reverse.

At the beginning of the study, global trends faced by modern society were considered. They relate to the social, economic and environmental environments. In the first approximation, these trends have a beneficial effect on the opportunities for economic and personal growth.

However, a number of studies show increased anxiety among young people about their future. This is primarily due to the fact that people are not ready to function in a new, rapidly changing environment. They just were not taught that. Because the educational environment was also not ready for such significant changes for a long time existing patterns.

The educational environment faced challenges dictated by modern trends. Experts note a significant obsolescence of theoretical knowledge and its accumulation, which does not correspond to the current needs of employers.

It is obvious that traditional and generally accepted educational technologies are no longer effective in the new conditions. They require adaptation to rapidly occurring changes. This section reviewed the best practices used in educational organizations located around the world.

In conclusion, it was shown the potential impact of human resources in the industry on the creation of opportunities to follow the current trends of changes taking place in the global world.

\section{Outline of new educational technologies for training personnel in the field of transport}

\subsection{Trends}

Among the significant trends in the socio-economic development of society, some can be identified. This is also a new technological revolution, the rapid development of which provoked the strongest competition. The economy is turning green - with a focus on 
sustainable development of society. At the same time, the economy refers to the global knowledge economy. In these conditions, all management decisions of a tactical and strategic nature must be made quickly and correctly. An ill-timed decision may mean a loss of competitive advantages for the company. That is why decisions must be justified from a scientific point of view. The knowledge economy forms a framework in which knowledge plays a crucial role and provides opportunities for economic growth. However, the growth may not be infinite, since the consumer society that has been functioning up to now leaves behind a number of acute environmental problems. Increased attention is paid to the sustainable development of the world, more and more people and companies are moving to a position of social responsibility [4], when the goals of the global society coincide with their own.

All these revolutionary changes in industry affected not only production, but also the labor market and the education system.

\subsection{Challenges}

For the current employer, it is not so much the amount of knowledge gained as the number of practical skills mastered by the university graduate during the training period [5]. The competence approach replaced the knowledge-based educational paradigm, in which knowledge, skills, and abilities were under focus. First of all, when hiring successful candidates the employer notes the formation of key competencies: "hard skills" and "soft skills". It should be mentioned that the life cycle of educational competencies is constantly decreasing [6], and the generally accepted single-peak model has given way to a three-peak model, where a person has a second (from 30 to 55 years) and a third (more than 55 years) working age. Successful implementation of this model allows a person to change about 8 times the type of activity that serves as a source of satisfaction of material needs during their life. You have to talk about education throughout your life. This phenomenon is called "lifelong learning". At the same time, it is important for the employer not to recruit new employees, but to retrain existing ones, since they already know the production process. Workers coming from other industries to transport require much more investment in "finishing training".

Modern challenges to the educational process are sometimes called VUCA, and modern educational technologies are required to teach graduates to resist VUCA [7].

\subsection{Requirements}

Recently, specialists in the field of logistics have become in demand in transport. However, different requirements apply to an employee in a logistics position in different countries. For example, the study of the authors [8] demonstrated that a candidate applying for this position in the Republic of Poland must have a driver's license, be able to work in a team and show leadership qualities. An important skill is the ability to delegate authority. At the same time, according to the heads of transport companies in the Republic of Lithuania, a potential candidate for the position of logistician needs to know Russian, as well as other foreign languages. This is a critical requirement. Knowledge of languages becomes a very important criterion when passing the test selection for a position in any company in the transportation industry.

In general, not only knowledge of the language is sufficient for labor migration. Employers pay attention to the fact that the applicants have received an international ELA / ECBL certificate issued by the scientific committees of the European Certification Board for Logistics (ECBL) together with the European Logistics Association (ELA). The certificate indicates that its owner meets the requirements that employers around the world 
impose on logisticians. For professional logisticians, it is important to have skills in Supply Chain Management (SCM), which is dictated by the rapid development of SCM concepts and technologies in business [9].

\subsection{Technologies}

\subsubsection{Smart factories}

Today, more and more attention is paid to processes in enterprises of any form of ownership. The process approach makes it easy to adapt to the constantly changing needs of customers. A company that focuses on processes becomes more flexible, which allows it to gain a competitive advantage. Often, when optimizing the production process through process improvement, companies are at the stage of implementing lean manufacturing. This is a concept that involves creating attractive value for the consumer by reducing all possible types of losses while maximizing the involvement of employees in this process. To clearly see the process from the point of view of value formation and losses, it must be divided into operations. The world practice of teaching lean production shows that the greatest educational effect is achieved when simulating a real production process. For example, the Karlstad Lean Factory was established in Sweden as part of the lean manufacturing concept. The factory simulates the real activity of industrial processing and material assemblying In this case, we use the process of assembling wooden chairs from IKEA [10].

However, it can be anything - some educational organizations both in Russia and abroad use LEGO to study the assembly process. Some educational organizations collect a real model of a fuel pump produced by KAMAZ (Novosibirsk state technical universityNSTU, Irkutsk state University of railway engineering-IrSURE), cars made of metal perforated plates (Siberian state university of railway engineering - SSURE). The visual representation of lean laboratories is shown in Figure 1.

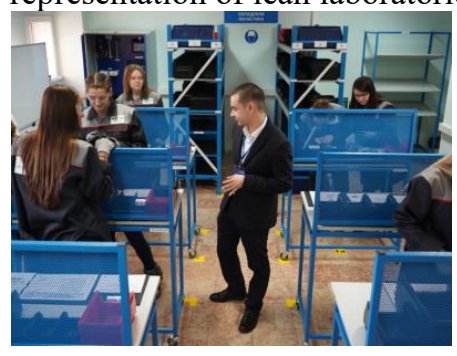

a.

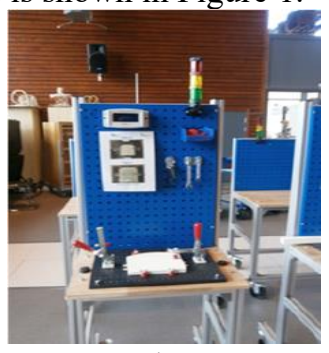

b.

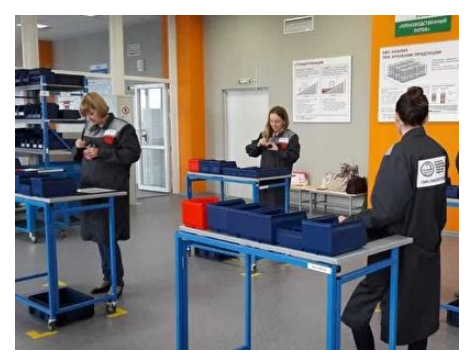

c.

Fig. 1. Lean laboratories: A-Russia (Irkutsk), B-Sweden (Karlstad), C-Russia (Novosibirsk) (Source: https://www.irgups.ru, [10], http://fb-nstu.ru/leanlab).

As you can see from the photos of lean laboratories in Russia and Sweden, they differ little from each other, which confirms the uniformity of training for the development of labor and student mobility.

\subsubsection{Research and student mobility}

The European research space (ERA) has been functioning since 2000 as an open space for knowledge exchange and scientific growth. It was adopted within the framework of the Lisbon strategy, which predetermined the main goal - to make Europe a "leading 
knowledge economy", which would be based on the" knowledge triangle": research, education, innovation [11].

Among the key conditions in ERA there was declared research mobility, creation of a favorable research environment, etc. To this end, conferences are regularly held for the mobility of research students in transport specialties, as well as for existing employees of transport enterprises in Europe. For example, the TRA (Transportation Research Area) is held every 2 years. The ETC (European Transport Conference) is organized annually by the Association of European Transport (AET) [12].

Students in transport specialties actively use the Maria Sklodovska-Curie Actions program. The program is one of the sub-programs of the European framework program "Horizon 2020". It involves the appointment of individual scholarships, the creation of educational networks, the exchange of academic staff, the coordination of scientific research, and so on. It should be noted that in this study, the work of one of the authors [13] was funded by the European Union's " Horizon 2020" program under grant agreement No. 869986. In general, research mobility is aimed at ensuring the "fifth freedom" for citizens. That is, freedom of movement of information and knowledge.

Russia also takes an active part in the achievement of the "fifth freedom"by its researchers. An important step in this direction was the official accession to the Bologna Declaration. Russian universities are implementing its provisions, the key of which are: accounting for the complexity of subjects in credit hours, the European assessment system, the European diploma supplement, and so on.

Similar to the European experience, various events are held to exchange experience and knowledge in the field of transport. The largest is "Transport week", which is a whole range of events. It has been held for 13 years in a row. In Siberia, which occupies most of Russia, the annual "Siberian transport forum" is held, since the transport infrastructure of Siberia has its own specifics and requires separate consideration. Such events are organized by the Ministry of transport of the Russian Federation. In addition, universities subordinate to the Ministry of transport of the Russian Federation hold annual conferences, Olympiads, and sports competitions, both for the exchange of scientific knowledge, and to assess their physical potential and the level of competence formation. Events can be of various formats: intra-university, inter-university, regional, national, international, etc. For example, there are regular competitions in applied swimming and water rescue "Ichthyander". There, students not only evaluate their level of preparation for working on water transport, but also exchange experience in the training process, as well as make new acquaintances, which is crucial for the implementation of student mobility programs.

\subsubsection{Virtual learning environments}

Virtual learning environments are one of the tools that help teachers train future employees in the transport industry. Under virtual learning environments B. Riera and B. Vigário [14] we understand a graphical complex of modeling dynamic systems that are controlled by peripheral control devices. The paper provides an example where students modify the environment using a virtual model of a smart home and get the opportunity to study the relationship between the parameters of the microclimate and natural and geographical conditions. This model increases students ' awareness of energy efficiency and safety when working with the power supply system.

In addition, high-quality educational video games can be used as simulators and training platforms as a virtual educational environment [15]. The use of this method significantly increases the interest in the educational process among students and at the same time, significantly reduces the labor intensity of conducting classes with a teacher. In the course of training, the teacher only controls the progress of the work, and the game itself is used 
repeatedly. However, to maintain harmony, the teacher must be familiar with the features of the game, must understand its game mechanics, and also get used to the legend. In transport, the use of virtual technologies (for example, such as VA and AR) is particularly important, since their use can significantly reduce the cost of implementing new equipment, reduce the risk of injury when testing new machines or mechanisms. In case of accidents or incidents, the skills to eliminate their consequences are carried out using virtual or augmented reality. Using VR and AR technologies makes it much easier to practice safe behavior in extreme situations.

\subsubsection{Corporate Universities}

The transportation industry does not always employ people who have graduated from specialized universities. Employers do not always have enough competencies that are formed during the implementation of educational programs at transport universities. Therefore, many transport companies both in Russia and around the world have their own educational centers, and sometimes even corporate universities [16]. For example, the American Corporation Boeing has various educational programs. All of them are divided into two blocks: pilot training programs and training programs for administrative and logistics staff of airlines.

Toyota Engineering Corporation also has its own training center, which implements various consulting projects and a standardization system, organizes internships, conducts corporate seminars and trainings.

At least such large Russian employers as PJSC AvtoVAZ, JSC TYAZHMASH, GAZ Group, and JSC Uralvagonzavod Research and Production Corporation have their own corporate universities [17]

Russian Railways, one of the leading companies in the Russian freight and passenger transport market, is the founder of the Russian Railways corporate university. The number of students enrolled in educational programs under agreements on education at the expense of individuals and legal entities is 10,873 people as of 14.07.2020. In 2020, the Corporate University of Russian Railways has celebrated its tenth anniversary, which shows the stability of demand for this form of education.

\subsubsection{STEAM-training}

It should be noted that STEM education, which involves a combination of science, engineering, mathematics and technology, is a priority area of national educational policy in Singapore, Canada, Japan, the United States, and Finland. In Russia, STEM education has been given special attention since 2010. It should be emphasized that in recent years, another letter "A" has been added to the STEM acronym, indicating creative orientation. Design plays a very important role in the transportation industry. Moreover, design is understood as an umbrella term in its broadest sense: graphic design, industrial, service and system design. Authors from France and Portugal [14] consider industrial automation training technologies and the advantages of STEM technology for this purpose. Authors from the Netherlands [11] based on the results of 75 Master's and 7 Doctoral theses proved the influence of design as one of the elements of STEAM training on the progress of the aviation industry. The Department of Delft University of technology, in partnership with the airline,there were identified the needs of passengers, developed a conceptual design and implemented the design of new high-comfort passenger seats. This required the creation of a special laboratory for prototyping (Figure 2). 

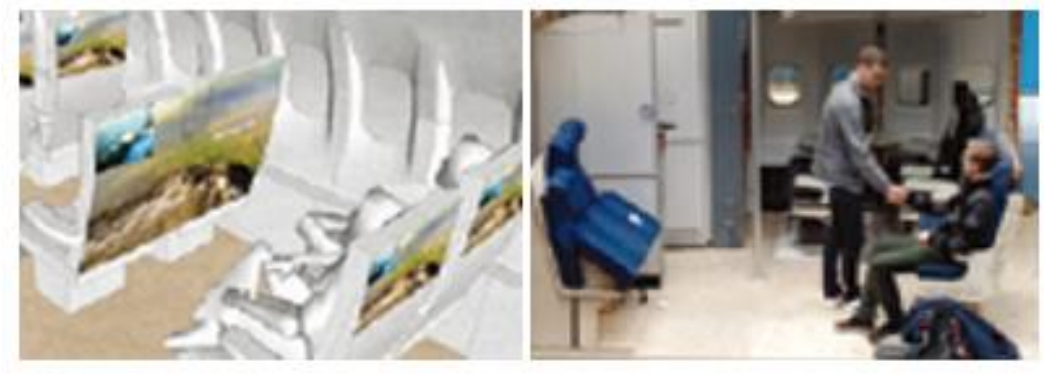

Fig. 2. Application of design for aviation industry training (Source: [11]).

It should be marked that the internal reserves of the industry are large, but they require the consolidation of efforts on the part of the state, industry, the service sector, users of transport services themselves, and the educational sector. only when working together, STEAM training will give positive results through a change in mentality-towards a customer-oriented way of thinking.

\subsubsection{Simulator training}

A number of researchers [18], [19], [20] prove that the training of professional marine deck officers can improve the management of ship variability and safety during critical operations at sea. Simulator training, according to the authors [20], allows students to obtain the ability to:

- to prevent adverse events through the recognition of anomalies and flexible problem solving;

- determine the limits of action based on general knowledge;

- manage the system with confidence.

Training is of great importance in transport, where the captain of a water or aircraft is responsible not only for the property entrusted to him, but also for the human lives of crew members and passengers. In aviation and marine educational institutions, simulators are used in whole complexes, where the real cabin of an aircraft or the real control panel of the navigation equipment of a ship is simulated (Figure 3 ).
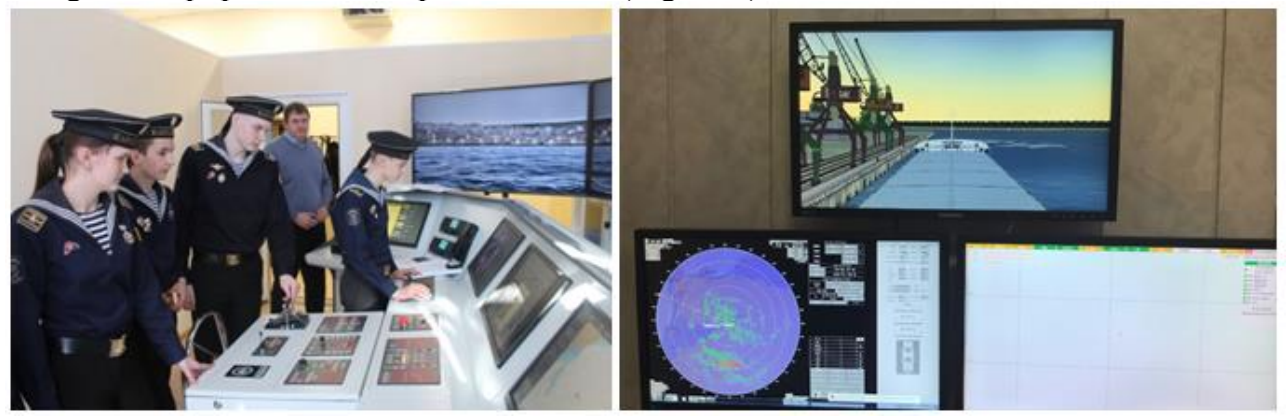

Fig. 3. The use of simulators for training navigators (Source: photo from the archives of SSUWT).

For example, the full-scale navigation simulator "NT PRO-5000", shown on the left in Figure 3, is used for training programs: "Radar surveillance and laying", " Use of automatic radar laying facilities (SARP)", "Use of navigation electronic map and information system (EKNIS)", "Maneuvering a ship", "Organization of navigation watch" and many others, 
which allows us to conclude that it is multifunctional and important in practical training of students.

\section{Results}

As a result of the research, an overview of educational technologies that are successfully used for training specialists in the field of transport is compiled. It should be noted that the most popular methods and tools associated with the use of digital and digital skills. However, physical navigation maps and maneuverable tablets do not lose their relevance. In the study of technical means of manual processing of radar information, students still use the logarithmic scale "Distance-Time-Speed". The speed is determined not by taking readings from the on-Board computer, but by using a compass and other plotting aids (parallel ruler, compasses, protractor, etc.).

It is important not to forget about the formation of craft skills in case the ship's control system suddenly fails. The critical skill can be to determine the location by the stars, and in an emergency, the ability to land a plane without autopilot and instruments. Only after mastering manual data processing it is possible to switch to automated and automatic one.

It is also an interesting observation that the current socio-economic trends in the world are both the cause and effect of technological revolutions in industry and transport. Trends dictate new necessary conditions for industry, industry forces the labor market to change, the labor market sends a request to the educational environment, which, in turn, changes the way of thinking. This is how a new trend is formed. Thus, we can say that the change in educational technologies triggers the formation of a new global trend in society.

\section{Conclusion}

In conclusion, we can say that for the training of specialists in transport, a set of technologies is used that allows you to fully master the competencies required by employers. Most of the technologies have a similar nature both in Russia and abroad. Unification of training allows graduates to make labor migration and feel like full members of the world community. However, whether employers are satisfied enough with the quality of training graduates using new educational technologies remains unclear and is the reason for the next study.

\section{References}

1. H. Nakano. A Study on the Features of the Evolution Processes and Business Models of Global Enterprises in the Transport Sector. Transportation Research Procedia 25 (2017) 3769-3788. DOI: https://doi.org/10.1016/j.trpro.2017.05.235

2. D.Reuschke, C. Mason. The engagement of home-based businesses in the digital economy. Futures. DOI: https://doi.org/10.1016/j.futures.2020.102542

3. A. Benešová, J Tupa. Requirements for Education and Qualification of People in Industry 4.0 // Procedia Manufacturing 11 (2017) 2195 - 2202. DOI: http://dx.doi.org/10.1016/j.promfg.2017.07.366

4. K.F. Yuen, J.M. Lim. Barriers to the Implementation of Strategic Corporate Social Responsibility in Shipping. The Asian Journal of Shipping and Logistic. 32(1). (2016). pp. 049-057. DOI: http://dx.doi.org/10/1016/j.ajsl.2016.03.006

5. Staffing search and recruitment of personnel on the basis of artificial intelligence technologies [Electronic resource] / A. A. Borisova, M. Rakhimberdinova, E. 
Madiyarova, I. Riazantseva, N. Mikidenko // Entrepreneurship and Sustainability Issues. (2020) Vol. 7, № 3. - P. 2456-2469. - Mode of access:

http://jssidoi.org/jesi/uploads/articles/27/Borisova_Staffing_search_and_recruitment_o f_personnel_on_the_basis_of_artificial_intelligence_technologies.pdf. - Title from screen - DOI: http://dx.doi.org/10.9770/jesi.2019.6.4(66) .

6. Lustina T. N. Modern approaches to building a career in the VUCA world / / Service in Russia and abroad. 4 (2019) pp. 169-177. DOI: http://dx.doi.org/10.24411/1995-042x2019-10415

7. S. Latha, P. Christopher. Vuca in Engineering Education: Enhancement of Faculty Competency For Capacity Building. Procedia Computer Science 172 (2020) 741-747. DOI: http://dx.doi.org/10.1016/j.procs.2020.05.106

8. K.Vaičiūtè, J.Skirmantienè, L. Domanskad Assessment of Transport Specialists' Competencies in Transport/Logistics Companies. Procedia Engineering. 187. (2017). pp. 628 - 634. DOI: http://dx.doi.org/10.1016/j.proeng.2017.04.423

9. Ya. Yu. Pavlova Educational standards for logistics activities // Actual problems of the economy of modern Russia. (2017). 34. ppS. 89-93. - URL: https://elibrary.ru/item.asp?id=32307416

10. L. J De Vin, L.Jacobsson, J.E.Odhe, A.Wickberg Lean Production Training for the Manufacturing Industry: Experiences from Karlstad Lean Factory. in: Procedure Manufacturing. 11 (2017) PP. 1019-1026. DOI: https://doi.org/10.1016/j.promfg.2017.07.208

11. R. A. Price, C. De Lille, K. Bergema. Advancing Industry through Design: A Longitudinal Case Study of the Aviation Industry. The Journal of Design, Economics, and Innovation Vol. 5, № 4, (2019). PP. 304-326. DOI: https://doi.org/10.1016/j.sheji.2019.07.003

12. G. A. Giannopoulos.Know-How Transfer and Training Issues for the Transport Research Professional. International Journal of Transportation Science and Technology Vol. 4 No. 2. PP. 159-178 (2015).

13. S. Secinaro, V. Brescia, D. Calandra, P. Biancone. Employing bibliometric analysis to identify suitable business models for electric cars. Journal of Cleaner Production 264 (2020) 121503. DOI: https://doi.org/10.1016/j.jclepro.2020.121503

14. B. Riera, B. Vigário. Home I/O and Factory I/O: a virtual house and a virtual plant for control education. IFAC PapersOnLine 50-1 (2017) 9144-9149. DOI: http://dx.doi.org/10.1016/j.ifacol.2017.08.1719

15. H. Nylund, V. Valjus, V. Toivonen, M. Lanz, H. Nieminen. The virtual FMS - an engineering education environment. Procedia Manufacturing 31 (2019) 251-257. DOI: http://dx.doi.org/10.1016/j.promfg.2019.03.040

16. E. Bucciarellia, F. Muratoreb, I. Odoardi. Consolidation processes of human capital in modern economic growth dynamics: an estimate based on the role of European corporate e-learning activities. Procedia Social and Behavioral Sciences 9 (2010) 622627. DOI: https://doi.org/10.1016/j.sbspro.2010.12.207

17. A. A. Galushkin The practice of creating "corporate universities" in the system of improving the competitiveness of educational products // Bulletin of economic security. (2017). 4 p. 307-310. - URL: https://cyberleninka.ru/article/n/praktikasozdaniya-korporativnyh-universitetov-v-sisteme-povysheniya-konkurentosposobnostiobrazovatelnyh-produktov 
18. J. Wermann, A. W. Colombo, A. Pechmann, M. Zarte. Using an interdisciplinary demonstration platform for teaching Industry 4.0. Procedia Manufacturing 31 (2019) DOI: https://doi.org/302-308. 10.1016/j.promfg.2019.03.048

19. V. A.Vinichenko, T. I. Zaiko Development of professional competencies of students in an active educational environment. Bulletin of the Novosibirsk state pedagogical University (2018) Vol. 8. №6. S. 155 through 166. https://doi.org/10.15293/22263365.1806.10

20. R. Chinoracký, T. Čorejová. Impact of Digital Technologies on Labor Market and the Transport Sector. Transportation Research Procedia 40 (2019) 994-1001 DOI: http://dx.doi.org/10.1016/j.trpro.2019.07.139. 